\author{
Н.Н. Аблажей* \\ Е.Н. Наземцева ${ }^{* *}$
}

«То, чего добивалось дореволюционное русское правительство, в 1920-е гг. совершалось стихийно» (к истории заселения Трехречья)
\end{abstract}

DOI: $10.31518 / 2618-9100-2019-4-5$

УДК 94(571.53):316.477-055.2

Выходные данные для цитирования:

Аблажей Н.Н., Наземщева Е.Н. «То, чего добивалось дореволюционное русское правительство, в 1920-е гг. совершалось стихийно» (к истории заселения Трехречья) // Исторический курьер. 2019. № 4 (6). Статья 5. URL: http://istkurier.ru/data/2019/ISTKURIER-2019-4-05.pdf
N.N. Ablazhey

E.N. Nazemtseva

\section{"What the pre-revolutionary Russian government tried to achieve, in the 1920s was done spontaneously" (to the history of the settlement of the Three rivers territory)}

\author{
DOI: $10.31518 / 2618-9100-2019-4-5$
}

\section{How to cite:}

Ablazhey N.N., Nazemtseva E.N. "What the prerevolutionary Russian government tried to achieve, in the 1920s was done spontaneously" (to the history of the settlement of the Three rivers territory) // Historical Courier, 2019, \# 4(6). Article5. [Available online:] http://istkurier.ru/data/2019/ISTKURIER-2019-405.pdf

Abstract. The publication introduces into scientific circulation a review prepared in November 1924 by the order of the Soviet administration of the Chinese Eastern Railways (KVZhD) and the Soviet Embassy in China by the employee of the KVZhD Department M. Bolshov. The review is devoted to the settlement in the border region of China by the refugees from the Trans-Baikal region - the areas of the Argun river region and the Three Rivers territory, located outside the concession territory ("the exclusion zone") of the KVZhD. The review describes the specifics of the Russian colonization of the Chinese border territory, the scale of the refugees in the period of the civil war, the settlement structure, the management system and administrative and legal status of migrants, as well as the specifics of economic activities of the immigrants.

Keywords: China; Trans-Baikal region; Three Rivers territory; KVZhD; border; refugees.

The article has been received by the editor on 10.08.2019.

Full text of the article in Russian and references in English are available below.

Аннотация. Публикация вводит в научный оборот обзорный Отчет, подготовленный в ноябре 1924 г. сотрудником Управления КВЖД М. Большовым по заказу советской администрации КВЖД и советского посольства в Китае. Отчет посвящен вопросам заселения беженцами из Забайкалья приграничья Китая - районов Приаргунья и Трехречья, расположенных вне концессионной территории («зоны отчуждения») КВЖД. В Отчете характеризуется специфика русской колонизации китайского приграничья, масштабов беженства периода гражданской

\footnotetext{
* Аблажей Наталья Николаевна, д-р. ист. наук, старший научный сотрудник Института истории СО РАН, доцент кафедры отечественной истории Гуманитарного института Новосибирского государственного университета (Новосибирск, Россия), e-mail: ablazhey@academ.org

Ablazhey Natalia Nikolaevna, Doctor of Historical Sciences, Senior Research Officer, Institute of History of the Siberian Branch of the Russian Academy of Sciences, Associate Professor, Institute of Humanities Novosibirsk State University (Novosibirsk, Russia), e-mail: ablazhey@academ.org

** Наземцева Елена Николаевна, д-р. ист. наук, старший научный сотрудник, Научно-исследовательский институт военной истории, Военная академия Генерального штаба ВС РФ (Москва, Россия), е-таil: elenanazz@mail.ru

Nazemtseva Elena Nikolaevna, Doctor of Historical Sciences, Senior Research Officer, Military History lnstitute, Military Academy of the General Staff, Russian Armed Forces (Moscow, Russia), e-mail: elenanazz@mail.ru
} 
войны, описывается поселенческая структура, система управления и административно-правовой статус мигрантов, специфика хозяйственной деятельности переселенцев.

Ключевые слова: Китай; Забайкалье; Трехречье; КВЖД; граница; беженство.

$* * *$

История российско-китайского приграничья наглядно демонстрирует непростую историю сосуществования государств-соседей, в полной мере отражая всю специфику и сложность отношений между странами на разных этапах, что наиболее остро ощущалось в контактных зонах - взаимозависимых приграничных территориях. Одной из таких контактных зон являлись (и являются до сих пор) приграничные территории российского Забайкалья и китайской Барги. Колонизация степных районов Барги (западной части плато Хулунбуир) переселенцами из России началась на рубеже XIX-XX вв., а пик освоения территории пришелся на 1910-1920-е гг. Миграционные потоки направлялись сюда из приграничных районов Забайкалья. В результате на территории Хулунбуира сформировалось два компактных района, заселенных русскоязычными колонистами - Трехречье и Приаргунье. Трехречье - район, расположенный в долинах рек Ган, Дербул и Хаул к северу от КВЖД; Приаргунье - западная части Барги, примыкающая к Забайкалью. Наиболее интенсивно заселялось Трехречье. Массовый приток населения в этот приграничный с Забайкальем район вызвали строительство КВЖД, революция и гражданская война, коллективизация. Доля выходцев из России в структуре населения региона постоянно повышалась и к середине 1920-х гг. численность русскоязычных поселенцев достигла 30 \% оседлого; переселенцев забайкальских бурят и тунгусов - 10 \% кочевого населения региона.

$\mathrm{B}$ течение первой половины XX в. район представлял собой российский этнокультурный анклав, известный как «Русское Трехречье», хотя наряду с русскими, здесь проживали буряты, эвенки, китайцы и японцы. Формирование Трехречья как контактной и переселенческой зоны стало возможным и благодаря, и вопреки границе. Ее «полупрозрачность» первоначально создавала широкие возможности для торговли и хозяйственной деятельности забайкальцев на приграничной китайской территории. Ослабление контактной и усиление барьерной функции границы повлекло изменение хозяйственных практик приграничного населения, способствуя оседанию и хозяйственному освоению. Официальное название Трехречья сегодня - Шивей-Русская волость городского округа Эргуна провинции Внутренняя Монголия. Здесь проживает около 5 тысяч китайских граждан русского происхождения (треть от их общей численности в стране).

Специфика Трехречья - русского анклава на китайской территории - привлекала и продолжает привлекать пристальное внимание специалистов разных областей: историков, этнологов, востоковедов, географов, социологов. Первые обследования региона, в том числе экспедиционные, были сделаны в период совместного советско-китайского управления КВЖД (1924-1935 гг.) усилиями специалистов Общества изучения Маньчжурского края $(\text { ОИМК })^{1}$ и сотрудников Экономического бюро КВЖД. Частично они отражены на страницах журнала «Вестник Азии» и «Вестник Маньчжурии», опубликованы в виде брошюр. В этой связи особо хотелось бы отметить публикации А.М. Баранова ${ }^{2}$ и В.А. Кормазова ${ }^{3}$. Данные издания первоначально были вполне доступны для советских специалистов, но впоследствии

\footnotetext{
${ }^{1}$ В феврале 1929 г. ОИМК трансформировано в Общество изучения культурного наследия Особого района восточных провинций (ОРВП).

${ }^{2}$ Баранов Алексей Михайлович (1865-1927), монголовед. Заведующий этнографическим отделом, член ОИМК. (См.: Баранов А.М. Барга: историко-географический очерк. Харбин: Изд-во ОИМК, 1925. 11 с.)

${ }^{3}$ Кормазов Владимир Алексеевич (1886(?) - (1960(1975?)), чиновник Главного переселенческого управления, сотрудник Экономического бюро КВЖД, деятель ОИМК. Кормазов В.А. Трехречье (за период 1924-1933 гг.) // Вестник Маньчжурии. 1934. № 5. С. 58-77; Он же. Чэнэхэн (По районам Барги) // Вестник Маньчжурии. 1933. № 13. С. 53-62; Он же. Кочевая Барга // Вестник Маньчжурии. 1928. № 8. С. 50-59.
} 
получили статус ДСП («Для служебного пользования»). На фоне улучшения советскокитайских отношений во второй половине 1940-1950-х гг. в СССР интерес к тематике Трехречья возродился, что нашло отражение в монографиях географов В.А. Анучина ${ }^{4}$ и И.Х. Овдиенко ${ }^{5}$. На рубеже 1960-1970-х гг. в «Советской этнографии» вышла серия статей уроженца Трехречья репатрианта А.М. Кайгородова ${ }^{6}$ п последующие публикации стали возможны только в начале 1990 -х гг. Часть материалов так и осталась неопубликованной ${ }^{7}$.

В силу своего приграничного статуса, значительной доли белоэмигрантов в структуре населения и деятельности японских оккупационных властей регион представлял особый интерес для советских спецслужб. Сохранился значительный документальный массив оперативной военной документации и делопроизводства НКВД и Красной Армии (погранвойска, «СМЕРШ», фильтрационные и архивно-следственные дела и пр., трофейное делопроизводство), хранящийся в архивах Российского государственного военного архива (РГ ВА), Центрального архива ФСБ РФ (ЦА ФСБ), ГА Хабаровского края (ГАХК), архивах УФСБ по Омской и Читинской областям. Регион представлен и в коллекциях Архива внешней политики РФ. Эти уникальные материалы оказались доступны для исследователей совсем недавно, благодаря «архивной революции», и лишь частично.

Пик интереса к Трехречью пришелся на 1990-е и первое десятилетие 2000-х гг., будучи связанным с интенсивным изучением истории русской эмиграции в Китае. В большей или меньшей степени Трехречье нашло упоминание почти в каждой книге по истории русских в Китае. Особого внимания заслуживают публикации Г.П. Белоглазова 8 , акцентирующего внимание на аграрной роли Трехречья. Регион упоминался в работах не только российских (в том числе эмигрантских) авторов, но также китайских и японских исследователей. Значительный массив воспоминаний о Трехречье и документальных материалов из частных коллекций репатриантов и их потомков представлен в сети Интернет.

В последнее время регион все больше привлекает внимание этнологов. Наиболее полно историография историко-этнологических исследований Русского Трехречья представлена в публикациях Ю.В. Аргудяевой 9 . Из последних работ, написанных в этом ключе, необходимо отметить монографии А.Г. Янкова и А.П. Тарасова «Русское Трехречье: история и идентичность» $(2012)^{10}$, основу которой составили как исторические документы, так и полевые материалы, и В. Кляюса «Русское Трехречье» $(2015)^{11}$, написанную в русле исторической антропологии. Среди опубликованных воспоминаний следует особо выделить книгу уроженца Трехречья П. Шахматова, построенную в жанре историко-этнографического описния ${ }^{12}$.

Несмотря на обилие публикаций, остро ощущается недостаток архивных материалов, в том числе статистико-экономического характера, полевых экспедиционных материалов Экономического отдела КВЖД и ОИМК, частично опубликованных в 1920-1930-х гг. Необходимо заметить, что более поздние обследования региона, проведенные уже

\footnotetext{
${ }^{4}$ Анучин В.А. Географические очерки Маньчжурии. М.: ОГИЗ, 1948. 300 с.

${ }^{5}$ Овдиенко И.Х.Внутренняя Монголия. М.: Гос. изд-во геогр. лит., 1954. С. 168 с.

${ }^{6}$ Кайгородов Анатолий Макарович (1927-1998), переводчик, этнограф, писатель. В 1954 г. прибыл в СССР из Китая по реэмиграции. Работал библиографом Всесоюзной государственной библиотеки иностранной литературы. (См.: Кайгородов А. Русские в Трехречье (по личным наблюдениям) // Советская этнография. 1970. № 2. С. 140-148; Он же. Эвенки в Трехречье // Советская. этнография. 1968. № 4. С. 123-131).

Кляус B. «Русское Трехречье» Маньчжурии. Очерки фольклора и традиционной культуры. М., 2015. 416 с.

${ }^{7}$ Кайгородов А. Потерянная земля: (Ист.-этногр. очерк). М., 1990-1994 (рукопись).

8 Белоглазов Г.П. Из истории русской гражданской земледельческой колонизации в Маньчжурии в начале ХХ в.// Россия и АТР. Владивосток, 1998. № 1. С. 13-18; Он же. Русская земледельческая культура в Маньчжурии (середина XVII - первая треть XX в.). Владивосток: Дальнаука, 2007. 184 с.

${ }^{9}$ Аргудяева Ю.В. Русское население в Трехречье // Россия и АТР. 2006. № 4. С. 121-134, и др.

${ }_{10}$ Янков А.Г., Тарасов А.П. Русские Трехречья: история и идентичность. Чита, 2012. 72 с.

${ }^{11}$ Кляус B. «Русское Трехречье» Маньчжурии. Очерки фольклора и традиционной культуры. М.: ИМЛИ РАН, $2015.416 \mathrm{c}$.

${ }^{12}$ Шахматов П. Трехречье. Воспоминания. Томск, издательство «Красное знамя», 2014. 344 с.
} 
Трехреченским бюро Бюро по делам русских эмигрантов в Маньчжоу-Го (БРЭМ), по сути, повторяли их структуру ${ }^{13}$. Эти отчеты наиболее полно характеризуют прежде всего поселенческую структуру и хозяйственную деятельность.

Публикуемый ниже документ представляет собой обзорный доклад секретаря управления КВЖД М. Большова, подготовленный по распоряжению первого советского управляющего дорогой А.Н. Иванова ${ }^{14}$ и поданный на имя посла СССР в Китае Л.М. Карахана ${ }^{15}$ в ноябре 1924 г. Обследование Трехречья и Приаргунья проводилась с целью оценки значения регионов для хозяйственных нужд КВЖД. Автор делает вывод о том, что начатая царским правительством политика колонизации полосы отчуждения КВЖД и приграничья была реализована в значительной степени благодаря стихийному беженству, вызванному политическими катаклизмами в России. Документ отложился в Архиве внешней политики РФ в фонде «Секретариат Л.М. Карахана» и публикуется впервые ${ }^{16}$. В приложении представлена подборка фотографий середины 1920-х гг. из той же архивной коллекции.

\section{Описание русских поселков в районах «Якеши», «Трехречье-Приаргунье» (в полосе КВЖД). 20 ноября 1924 г. Харбин}

Революционные события в России и последующая Гражданская война вызвали активное движение в приграничных районах Забайкалья. Начиная с 1919-1920 гг. к северу от КВЖД стали образовываться беженские поселки. К середине 1920-х гг. процесс приспособления к новым местам завершился. Вне полосы отчуждения образовались пять поселков беженцев: Касынор, Могатуй, Тынхэ, Горбунор и Нажимбулак.

В отличие от поселков Трехречья и долины реки Аргуни данные поселки были в основном скотоводческие. Это, в свою очередь, было обусловлено политикой монгольских властей, которые по религиозным мотивам, а также препятствуя китайской колонизации, запретили распахивать землю.

Таблиия 1

\section{Состав населения в пределах поселков}

\begin{tabular}{|l|c|c|c|c|c|}
\hline \multirow{2}{*}{\begin{tabular}{c}
\multirow{2}{*}{ Казаков } \\
(число домов)
\end{tabular}} & \multirow{2}{*}{ Бурят } & \multicolumn{2}{|c|}{ численность } & \multirow{2}{*}{ Всего } \\
\cline { 4 - 5 } & Касынор юрт) & русских & бурят & населения \\
\hline Тынхэ & 85 & - & 540 & - & 540 \\
\hline Могатуй & 65 & 30 & 465 & 200 & 665 \\
\hline Горбунор & 4 & - & 35 & - & 35 \\
\hline Нажимбулак & 15 & 50 & 100 & 250 & 350 \\
\hline Всего & 183 & 35 & 70 & 160 & 230 \\
\hline
\end{tabular}

Все эти поселения состояли из забайкальских беженцев, перекочевавших в период гражданской войны со своими довольно многочисленными стадами на китайскую территорию и обосновавшиеся в районе поселка Якеши.

\footnotetext{
${ }^{13}$ Пара таких отчетов за 1941 и 1944 г. представлена в трофейных коллекциях БРЭМа (ГА ХК. Ф. 830. Оп. 1. Д. 75, Архив УФСБ по Читинской области. Д. 66).

${ }^{14}$ Иванов Алексей Николаевич (1892-1937), советский партийный и хозяйственный деятель. С 1920 г. сотрудник НКПС. С декабря 1922 г. проживал в Китае. 10.1924-04.1926 гг. -1-й советский управляющий (товарищ Председателя) КВЖД. В 1927 г. - исключен и восстановлен в рядах ВКП(б). В 1937 г. - зам. начальника Главного строительного управления НКПС СССР. Осужден 31.10.1937 ВК ВС СССР к ВМН. Реабилитирован BК ВC CCCP 22.02.1958.

${ }^{15}$ Карахан Лев Михайлович (1889-1937), советский дипломат. Старшина дипломатического корпуса в Пекине (1925), зам. наркома НКИД СССР (1926-1934). Осужден 20.09.1937 ВК ВС СССР к ВМН. Реабилитирован 12.12.1956 ВК ВС СССР.

${ }^{16}$ Единичные фрагменты Отчета вошли в текст рукописи диссертации Е.Н. Наземцевой (См.: Наземцева E.H. Политико-правовое положение русских эмигрантов в Китае в китайско-советских отношениях 1920-1949 гг. : дисс. ... д-ра ист. наук. М., 2018. С. 194-197.
} 
Причины такого кочевого образа жизни заключались в необходимости иметь большую площадь для выпаса скота.

В районе расположения поселков Горбунор и Наджибулак в летнее время собирались десятки больных беженцев для лечения в минеральных ключах. С каждым годом приток больных увеличивался. В 1923 г. составил около 50 человек. Следует отметить, что приезжали на лечение даже из Маньчжурии.

Средняя усадьба беженца-казака имела площадь около 50 саженей длиной и 25 саженей шириной, была обнесена плетнем. Обычным типом жилых построек в поселках вне полосы отчуждения являлась землянка.

Не менее распространенным типом жилья служили и плетенки, формировавшиеся землей. Изредка встречались забайкальские бревенчатые избы с деревянным полом.

В поселках отсутствовала ветеринарная помощь, что серьезно препятствовало развитию скотоводства. В то же время обилие молочного скота в районе Якеши возродило целый ряд маслодельных заводов с отделениями по закупке молока.

Однако работа маслодельных артельных заводов, несмотря на благоприятные условия, в которых они находились, благодаря покровительству Земельного отдела КВЖД, была малопродуктивна. Причина этого заключалась в неумелой постановке сбыта масла.

Население поселков также занималось охотой. Некоторые были заняты на Воронцовских концессиях. Охотились на белку, изюбря, лося, лису, волка.

Довольно большим подспорьем в хозяйстве беженцев было также вязание из овечьей шерсти шалей, перчаток, шарфов и других предметов одежды.

Беженцы несли как денежные, так и натуральные повинности. К денежным относились: плата за посев с 1 десятины - $5 \$^{17}$, плата с головы взрослого скота $-1 \$$, плата с молодняка $0,6 \$$, плата за сенокос с пуда сена $-0,02 \$$, «пожалование старшине с взрослой души» $-0,3 \$$. Старшина избирался домохозяином на годичный срок и утверждался местным китайским Полицейским Начальником.

Кроме этого поселяне ежегодно уплачивали Земельному отделу КВЖД арендную плату за усадьбу - 0, 03 руб. с квадратной сажени.

Все денежные налоги с реализации урожая собирались китайскими чиновниками. «Особенно энергично» взыскивались налоги за посев. Например, в 1924 г. китайские чиновники потребовали уплаты еще до того, как беженцы успели обмолотить собранное зерно. Но так как деньги у беженцев появлялись только после продажи урожая, а китайское руководство запрещало вывозить его до уплаты налогов, казаки вынуждены были обращаться к концессионеру Воронцову ${ }^{18}$. Последний ссужал в долг с обязательством в месячный срок погасить его пшеницей по цене 1 руб. 30 коп. за пуд, хотя рыночная цена составляла не менее 2 \$. Если долг не уплачен в течение месяца, то цена зерна понижалась на 10 копеек.

К натуральной повинности относилась подача лошадей для удовлетворения нужд китайской администрации.

Таким образом, русские поселки, прочно обосновавшиеся в районе к северу он станции Якеши в 1920-1924 годы, способствовали развитию местности. Как отмечалось в докладе «описание русских поселков в районах Якеши, Трехречье, Приаргунье», «кроме монгольских стад и табунов пасутся забайкальские улучшенные породы рогатого скота - появились маслодельные заводы, а расположении пристанционной полосы зеленеют поля хлебных культур». В связи с этим руководством КВЖД было принято решение обеспечить поселки

\footnotetext{
${ }_{17}^{17}$ Китайский доллар (китайский юань).

18 Воронцовские лесопромышленные концессии принадлежали братьям Михаилу и Дмитрию Воронцовым. Предприятия специализировалось на лесозаготовках в районах Большого Хингана. В 1925 г. Воронцовы учредили при участии КВЖД и Цицикарского правительства «Хаминское лесопромышленное товарищество», после конфликта на КВЖД 1929 г. концессия перешла «Китайско-восточному Хайлинскому лесопромышленному товариществу».
} 
ветеринарной помощью, организовать прокатные пункты вне полосы отчуждения и наладить продажу с/х машин для развития земледелия в крае.

В Приаргунье - Западной части Барги, примыкающей к Забайкалью, после Гражданской войны обосновались зажиточные станичники - забайкальские казаки. Издавна они были тесно связаны с Баргой. Недостаток лугов на родине побуждал забайкальцев перегонять свой скот через Аргунь на выпас, а также заготовлять сено на зимний период стойлового содержания. В 1920-е годы в прибрежной части р. Аргуни возникло 18 поселков, а также несколько хуторов в отрогах Хингана, в которых проживали забайкальские казаки, вынужденные окончательно покинуть родину.

Беженские поселки, обосновавшиеся на правом берегу Аргуни, носили названия русской стороны. Заселение этих мест относится к 1918-1919 г. Кроме этих поселков здесь были разбросаны китайские заимки. Население в основном состояло из китайцев, русских беженцев забайкальцев, незначительного числа граждан СССР и кочевников-звероловов, которых местные жители называли якутами. Однако преобладающим элементом являлись китайцы. Из общей численности в 4000 человек, на долю русских приходилось не более 1300 человек.

Следует отметить, что все цифровые данные являются весьма приблизительными, так как были составлены на основании слов местных жителей. Точной регистрации населения не велось. Кроме того, процесс прочного оседания не был завершен, так как часть Забайкальцев-беженцев периодически возвращалась обратно на родину, часть эмигрировала к прочно устроившимся в Китае родным, другая часть перекочевывала в район Трехречья.

Беженцы подчинялись Шевысянскому уездному начальнику и управлялись выборными лицами - старшинами, которые утверждались местными властями. Должность старшины в некоторых поселках оплачивалась, но оклад никогда не превышал 15 \$.

Налоги и повинности, которые несло население, устанавливались таможенным и полицейским Управлением. Таможенное Управление взимало за выпас, сенокос, трубы, полицейское - за посев. В частности, за выпас взималось: с крупного рогатого скота и лошадей - 1,35 \$, с молодняка - 0,65 \$, с овцы - 0,25 \$, за сенокос с 1000 пудов - 17 \$. Натуральные повинности составляли - подачу лошадей полицейским чинам при разъездах по служебной надобности. Те же налоги, кроме натуральной повинности, несли и граждане $\mathrm{CCCP}$, если они имели хозяйство на китайской территории. Однако когда жители поселков советские граждане арендуют для своих сельскохозяйственных нужд целую падь, тогда они освобождались от прочих видов уплаты.

Следует отметить, что арендование земли советскими гражданами расширилось в 1924 г., особенно в районе г. Шевысян. Переход границы для удовлетворения сельскохозяйственных нужд советскими гражданами из приграничных поселков происходил с разрешения местных советских властей. Им выдавались особые пропуска:

Пропуск

Дан сей гр в том, что ему разрешается беспрепятственный проезд на китсторону сроком на « » суток с «__ » по « » 1925 г. для проведения на таковой сельскохозяйственных работ.

Проезд за границу разрешается через Погранзаставу № села с неуклонным обязательством явки на регистрацию при данной заставе при выезде и возвращении обратно.

Основание: Приказ НПОГПУ по ДВО от за № и удостоверение. Удостоверение Сельсовета № от Замнач. Погротревар Печать Погранотдела. 
Ранее пропуск (до 1925 г. - Авт.) выдавался сроком на 1 месяц с уплатой 60 коп. С 1925 г. срок был увеличен до 3 месяцев. Переход границы гражданами СССР для удовлетворения своих сельскохозяйственных нужд объяснялся с одной стороны тяжестью налогов, а с другой - установлением 8-часового рабочего дня для рабочих по найму в сельском хозяйстве.

Кроме того, многие жаловались на тяжесть сельскохозяйственного налога - 25 \% всех единоличных хозяйств.

Из урожая Приаргунья зерно на рынок в Хайлар поступало в незначительном количестве, в основном контрабандой из Забайкалья, скапливалось в китайских бакалейках, а затем ввозилось в зимнее время приаргунскими и трехреченскими беженцами.

Численность скота установить было трудно, так как жители старались скрыть эту информацию, боясь повышения налогов. Тем не менее, известно, что среднее хозяйство составляло 5 лошадей, 10 голов крупного рогатого скота, 20 овец, 5 свиней.

Главными предметами торговли являлись зерно, рассыпное золото с территории СССР, мануфактура, спирт, чай, предметы одежды.

Прочному обоснованию беженцев в районе Барги способствуют богатый чернозем, остречная луговая растительность, золотоносные пески, пушнина. Постепенно землянки были заменены на бревенчатые избы.

Руководство дороги считало, что развитие сельского хозяйства и торгово-промышленной жизни, а также колонизация пустынных монгольских степей выгодны для дороги.

В Трехречье также после Гражданской войны обосновались беженцы из России забайкальские казаки. Они обустроили поселения по берегам Гана, Дербула и Хаула. Здесь же нашли приют и кочующие инородцы - буряты, тунгусы. Это привело к развитию соответствующего типа станичников - забайкальских хозяев с многочисленными стадами, табунами и пашнями.

Преобладающим населением в этих краях являлись монголы, китайцы и русские, прочно осевшие в Трехречеье. В долине р. Гана русских - 943 чел., р. Дербула - 794, р. Хаула - 162, p. Аргуни - 1162. Таким образом, всего русских - 3061 чел. Число китайцев с воинскими частями в Трехречье не более 100 чел., на Аргуни - 6808 чел.

Таким образом, общая численность оседлого населения с китайскими воинскими частями - около 10000 чел.

Однако эмиграционное движение продолжалось и в течение 1920-х гг. Однако обратного движения - из Трехречья в Россию не было. Как правило, казаки оставались у своих родственников, прочно обосновавшихся в этих краях раньше. Постепенно наспех сколоченные постройки заменялись прочными избами. Усадьба огораживалась забором, появлялись хозяйственные постройки. В некоторых поселках, например - В. Кулях - осели старообрядцы, построили здесь свои церкви.

Стремлению к формированию в Трехречье оседлых поселений способствовала китайская администрация. В частности, китайскими властями в обязанность поселковых старшин вменялось принуждение поселенцев к распашкам, препятствие в разрешении на переезд в другие районы, при разрешении же переезда запрещалось продавать и разбирать постройки для их переноса.

Управляли беженцами помимо Полицейского управления, находившегося в пос. Щучьем, особый местный орган - Заведующий беженцами и институт старшин с помощниками. Заведующий беженцами назначался Начальником Провинции и подчинялся начальнику Полиции или его помощнику. На нем лежали следующие обязанности: распределение подвод, обслуживающих китайских чиновников при разъездах по служебной надобности, введение наряда на работы по постройке, ремонту помещений для китайских административных лиц, введение наряда по снабжению дровами административных учреждений. Кроме этого Заведующий выполнял роль мирового судьи. За свои обязанности он ежемесячно с каждой семьи получал по 25 коп.

Права и обязанности старшин определялись инструкцией, которая гласила: 
1. Хуторской старшина назначался Комиссией с участием членов полиции сроком на один год; помощник ему избирался обществом на три месяца. Их имена сообщались Заведующему беженцами.

2. Хуторской старшина являлся хозяином своего хутора и района, он был обязан знать лично всех людей своего хутора, как русских, так и китайцев и иметь именной список с указанием фамилий, отчеств и имен, членов семей, возраста, численность рогатого скота, лошадей, баранов, телег, машин, сох и борон, и также из какой станицы прибыл беженец.

3. Хуторской старшина должен был следить за прибывающими на хутор людьми. Неизвестные лица вне зависимости от их подданства должны были высылаться в Щучью под конвоем в распоряжение полиции.

4. Хуторской старшина должен был строго следить за порядком, препятствовать нападениям хунхузов.

5. Старшина также должен был контролировать выпас скота, не допускать вытаптывания скотом пашен и сенокосов.

6. Привлекать жителей к «продуктивному труду»: сеять хлеб, картофель, капусту и т. д.

7. Выполнять все требования полиции и заведующего беженцами.

8. Для распределения нарядов на работы, подводы и другие натуральные повинности хуторской старшина должен был вести списки.

9. «каждый старшина должен заботиться за своих жителей, чтобы жители искали заработки».

10. Старшина должен был способствовать устройству на работы «темных жителей».

В Трехречье главными занятиями населения являлись скотоводство, земледелие, торговля и охота. Общее число лошадей в Трехречье составляло около 2000, рогатого скота - 10000 , овец - 28 000. Безусловно, главной причиной оседлости всех забайкальских скотоводческих хозяйств, перешедших границу после Гражданской войны, были богатейшие луга края. Общим же тормозом в развитии скотоводства как и в других районах было отсутствие ветеринарной помощи. Между тем в 1920-е гг. случались эпидемии чумы у скота.

Многочисленные стада рогатого скота поселенцев и кочевников способствовали возникновению маслодельных заводов с отделениями по скупке молока. К середине 1920 -х гг. в Трехреченском районе было три завода: Шведский завод Тернлюма в В. Кули с отделением в Лабдарине; завод Продовольственно-Промышленного Товарищества в Щучьем и завод маслодельной артели.

Кроме того, по данным представителя одной Английской компании по сбору и закупке шерсти и пушнины в Хайларе и Маньчжурии, Трехреченский [район] давал на рынок не менее 5 тысяч пудов овечьей шерсти и 125 пудов козьего пуха, причем из общего количества овечьей шерсти около 1500 пудов оставалось для местной кустарной выделки.

Причины развития земледелия заключались во-первых - в невозможности вернуться на родину, во-вторых - в дороговизне забайкальского хлеба, в-третьих - удаленности от железной дороги, а следовательно - от производящих районов.

Из 25 поселков, расположенных по долинам р. Гана, Дорбула и Хаула - к 1924 г. 24 приступили к распашке земель. Прежде чем сеять, каждый из поселян должен был получить разрешительное свидетельство через полицейское Управление. В свидетельствах указывалось, какое количество земли сдавалось под пашню и не указывалось, что поселенец должен был платить. Плата устанавливалась после реализации урожая. В данной местности китайским руководством применялся способ так называемой колонизации через товарищества. Сущность этой системы заключалась в том, что Товарищества, получив от правительств свободные земли, кредит, или с уплатой первоначально незначительных задатков принимали все меры к заселению края. Расходы Товарищества по заселению покрывались поселенцами в виде налогов за пользование землей.

Эта система колонизации позволяла правительству, не затрачивая правительственных денег, заселять свободные земли, но с другой стороны, поселенцы отдавались на 
произвол «Товариществ», которые всеми мерами стремились нажиться на поселенцах. Обычно в эти «Товарищества» входили административные лица района - начальник таможни, полицейские начальники и др. Общее количество распаханной земли на подобных условиях составляло 450 десятин.

Другими занятиями Трехреченского и Приаргунского районов относилась охота на зверей и дичь, а также рыболовство.

Кроме того, имелись и второстепенные заработки - кустарное производство из овечьей шерсти и собачьего пуха предметов одежды - кофт, рукавиц, фуфаек, а также пчеловодство.

В торговле Трехреченского района выделялось два периода: торговля до появления маслодельных заводов относится к первым годам эмиграции. В этот период в Трехреченский район приехало довольно много китайцев, которые в каждом хуторе и поселке открыли по нескольку мелких лавок. Пользуясь удаленностью района от торговых пунктов, владельцы этих лавок удваивали и даже утраивали стоимость привезенных из Хайлара товаров и активно открывали кредит для поселенцев. В результате в руки этих китайских купцов перешло довольно много скота поселенцев - в погашение долгов. После появления в 1922 г первого маслодельного завода, при котором были свои лавки, поселенец, сдавая молоко, мог получать товары по цене не более чем на 20-30 \% дороже, чем в Хайларе. В результате заводские лавки вытеснили китайских предпринимателей.

Несмотря на удаление Трехречья от железной дороги и торговых пунктов, его часто посещали хайларские и харбинские промышленники. Все торговые операции фирмы вели через скупщиков, которые вступали в непосредственную связь с производителями.

Открытие границы способствовало увеличению торгового оборота, а также притоку грузов по КВЖД.

Налоги, взимавшиеся в Трехречьи и Приаргунье, также подразделялись на денежные и натуральные. К денежным относились: налоги на пользование топливом (3-16\$), за пользование сенокосом, за лошадей и скот с головы (за крупный рогатый скот $-1,20-1,60$ к., молодняк до 2 лет - 0,6 - 0,70, овцу более 1 года - 0,25-0,30), за посев хлебов - выкуп разрешительного свидетельства - 1,120, выкуп разрешительного свидетельство на право охоты - 3 р., жалование заведующему - 20 к. с домохозяина. К натуральным относились: плата с десятины посева (плата предполагалась только пшеницей) - 6-13 пудов с обязательной доставкой в полицейское управление пос. Щучье.

Виды натуральной повинности были следующие:

1. Подводная повинность и обязанность предоставлять пароконную телегу для полицейских при исполнении ими служебных обязанностей.

2. Ежедневное снабжение водой полицейского Управления в Лабдарине и Щучьем.

3. Ежегодная заготовка дров для нужд полиции.

4. Ежегодное сенокошение для нужд полиции.

5. Подготовка земли под огород.

6. Ремонт помещений, занятых полицейским Управлением и чиновниками.

7. В тревожное время - появления в районе Трехречья хунхузов, партизан, или же красных отрядов - охрана китайских полицейских чиновников.

Таким образом, забайкальцы, занимавшиеся на родине скотоводством, обосновавшись в Китае, не оставляли это занятие, а наоборот переходили к землепользованию. Распашки постоянно увеличивались, чему способствовала богатейшая почва. В результате у поселенцев не возникало желания менять вновь обустроенные места. С другой стороны, это свидетельствовало о постепенном освоении русскими диких монгольских долин. То, чего добивалось дореволюционное русское правительство [,] в 1920-е гг. совершалось стихийно.

АВП РФ. Ф. 08. Оп. 7. П. 8. Д. 17. Л. 17-122. Машинописный подлинник. Сопроводительная записка «Послу СССР в Китае Л.М. Карахану. По распоряжению Управляющего дорогой товарища Иванова, при сем препровождается Вам описание: "Русские поселки района станции "Якаши" и "Трехречье-Приаргунье. Секретарь управления дороги М. Большов». 


\section{Лumepamypa}

Анучин В.А. Географические очерки Маньчжурии. М.: ОГИЗ, 1948. 300 с. Аргудяева Ю.В. Русское население в Трехречье // Россия и АТР. 2006. № 4. С. 121-134. Баранов А.М. Барга: историко-географический очерк. Харбин: Изд-во ОИМК, 1925. 11 с. Белоглазов Г.П. Из истории русской гражданской земледельческой колонизации в Маньчжурии в начале ХХ в. // Россия и АТР. Владивосток, 1998. № 1. С. 13-18.

Белоглазов Г.П. Русская земледельческая культура в Маньчжурии (середина XVII - первая треть XX в.). Владивосток: Дальнаука, 2007184 с.

Кайгородов $A$. Русские в Трехречье (по личным наблюдениям) // Советская этнография. 1970. № 2. C. 140-148.

Кайгородов А. Эвенки в Трехречье // Советская. этнография. 1968. № 4. С. 123-131.

Кляус B. «Русское Трехречье» Маньчжурии. Очерки фольклора и традиционной культуры.М.: ИМЛИ РАН, 2015. 416 с.

Кормазов В.А. Кочевая Барга // Вестник Маньчжурии. 1928. № 8. С. 50-59.

Кормазов В.A. Трехречье (за период 1924-1933 гг.) // Вестник Маньчжурии. 1934. № 5. C. $58-77$.

Кормазов В.А. Чэнэхэн (По районам Барги) // Вестник Маньчжурии. 1933. № 13. С. 53-62.

Наземцева E.H. Политико-правовое положение русских эмигрантов в Китае в китайскосоветских отношениях 1920-1949 гг. : дисс. ... д-ра ист. наук. М., 2018. 474 с.

Овдиенко И.Х.Внутренняя Монголия. М.: Гос. изд-во геогр. лит., 1954. С. 168 с.

Шахматов П. Трехречье. Воспоминания. Томск, издательство «Красное знамя», 2014. 344 с. Янков А.Г., Тарасов А.П. Русские Трехречья: история и идентичность. Чита, 2012. 72с.

\section{References}

Anuchin V.A. Geograficheskie ocherki Manchzhurii [Geographical essays of Manchuria]. Moscow: OGIZ, 1948. 300 p.

Argudiaeva Y.V. Russkoe naselenie v Trekhrechie [Russian population in the Three rivers area] // Rossiia i ATR, 2006, № 4. P. 121-134.

Baranov A.M. Barga: istoriko-geograficheskiy ocherk [Barga: historical and geographical essay]. Harbin: Izd-vo OIMK, 1925. 11 p.

Beloglazov G.P. Iz istorii russkoy grazhdanskoy zemledelcheskoy kolonizatsii v Manchzhurii v nachale XX v. [From history of Russian civil agricultural colonization in Manchuria in the beginning of the 20th century] // Rossiia i ATR. Vladivostok, 1998, № 1. P. 13-18.

Beloglazov G.P. Russkaya zemledelcheskaya kultura v Manchzhurii (seredina XVII -pervaia tret XX v.) [Russian agricultural culture in Manchuria (the middle of $17^{\text {th }}-$ the first third of the $20^{\text {th }}$ century]. Vladivostok: Dalnauka, 2007. 184 p.

Kaigorodov A. Russkie v Trekhrechie (po lichnym nablyudeniiam) [Russians in the Three rivers area (after personal observations] // Sovetskaya etnografiya, 1970, № 2. P. 140-148.

Kaigorodov A. Evenki v Trekhrechie [Evenks in Three rivers area]// Sovetskaya etnografiia, 1968, № 4. P. 123-131.

Kliaus V. "Russkoe Trekhrechie" Manchzhurii. Ocherki folklora i traditsionnoy kulturi ["Russian Trekhrechie" Of Manchuria. Essays of folklore and traditional culture]. Moscow: IMLI RAN, 2015. $416 \mathrm{p}$.

Kormazov V.A. Kochevaia Barga [Nomadic Barga) // Vestnik Manchzhurii, 1928, № 8. P. 50-59.

Kormazov V.A. Trekhrechie (za period 1924-1933 gg.) (The Three rivers area (for the period of 1924-1933) // Vestnik Manchzhurii, 1934, № 5. P. 58-77.

Kormazov V.A. Chenekhen (Po raionam Bargi) [Chenekhen (by the districts of Barga] // Vestnik Manchzhurii, 1933, № 13. P. 53-62.

Nazemtseva E.N. Politiko-pravovoe polozhenie russkikh emigrantov v Kitae v kitaisko- 
sovetskikh otnosheniah 1920-1949 gg. : diss. ... d-ra ist. nauk. [Political and legal status of Russian emigrants in China in the Sino-Soviet relations of 1920-1949: Doctor of historical sciences thesis]. Moscow, 2018. $474 \mathrm{p}$.

Ovdienko I.H. Vnutrenniaia Mongoliia [Inner Mongolia]. Moscow: Gos. izd-vo geogr. lit., 1954. $168 \mathrm{p}$.

Shakhmatov P. Trekhrechie. Vospominaniia [The Three rivers area. Memories]. Tomsk. Izd-vo "Kranoie Znamia", 2014. 344 p.

Yankov A.G., Tarasov A.P. Russkie Trekhrechia: istoriia i identichnost [Russians of the Three rivers area: history and identity]. Chita, 2012. 72 p.

Статья поступила в редакцию10.08.2019 г. 